\title{
EDITORIAL
}

\section{Cigarette smoking, cytogenetic abnormalities, and acute myelogenous leukemia}

Leukemia (2007) 21, 1137-1140. doi:10.1038/sj.leu.2404698

Government advisories warning of the ill-effects of using tobacco products date back at least to the proclamation of James I of England (James VI of Scotland) (1566-1625), who in 1604 , the year he commissioned the King James version of the Bible, described their use as 'A custome lothsome to the eye, hatefull to the Nose, harmefull to the braine, dangerous to the Lungs, and in the blacke stinking fume thereof, neerest resembling the horrible Stigian smoke of the pit that is bottomlesse'. ${ }^{1}$ Although published anonymously, there was apparently little doubt about the author of those remarks, the King of England. The King also required Thomas Earle of Dorset, High Treasurer of England, to collect a tax on each pound of tobacco imported. It is said that when the royal exchequer grew from the tobacco tax imposed on imports from the Virginia colony, James's criticism of using tobacco products became muted. In any event, ascribing one more disease, acute myelogenous leukemia (AML), to the effect of smoking on its victims may add little to the substantial arguments that already exist for abstention.

The relationship of cigarette smoking to the incidence of AML was suspected in the 1970s and the studies alluding to this relationship were commented on in a Department of Health, Education and Welfare report on Smoking and Health in 1979. In 1986, the evidence for the association was reviewed and considered to be inconclusive. $^{2}$

Although an association of cigarette smoking and AML has not been a universal finding in the studies on this topic, the majority of studies in the last 20 years have reported a statistically significant, moderate relationship (reviewed in Thomas et al. ${ }^{3}$ and Brownson et al. ${ }^{4}$ ) with a relative risk of about 1.4 for AML among cigarette smokers compared to nonsmokers and the relative risk approaching 2.0 for heavy smokers. ${ }^{3,4}$ In 2004, the Surgeon General of the United States ${ }^{5}$ and the International Agency on Research in Cancer of the World Health Organization, ${ }^{6}$ each concluded, based on the data available, that cigarette smoking caused AML. Studies measuring population-attributable risk, the proportion of all cases of AML that can be attributed to cigarette smoking, have reported values ranging from 14 to $31 \% .^{3,4,7-9}$ If the lowest value is true, cigarette smoking would be the most prevalent exogenous cause of AML. The risk of clonal cytopenia and oligoblastic myelogenous leukemia (myelodysplastic syndrome) has also increased in cigarette smokers, as would be expected given that these are more slowly progressive forms of AML. ${ }^{10,11}$ Cigarette smoking has also been associated with shorter remission and survival durations and more pulmonary infections during the period of severe pancytopenia induced by therapy of AML. ${ }^{12}$

There has also been interest in the relationship of paternal or maternal smoking before or during pregnancy to the incidence of acute leukemia in the child. Conflicting results of these relationships have been published, including a relationship to paternal smoking, ${ }^{13}$ maternal smoking ${ }^{14}$ and no relationship to parental smoking. ${ }^{15,16}$ Some studies found a relationship with childhood acute lymphocytic leukemia (ALL), 13,17,18 some with childhood $\mathrm{AML}^{14,19}$ and occasionally with both acute leukemias. $^{20}$ Because the genotoxic effects of cigarette smoke on susceptible lymphohematopoietic cells appear to be relatively weak, additional appropriately-designed studies would be needed to settle the question of parental smoking and acute leukemia. ${ }^{21}$ The evidence for the initial mutation occurring in utero in some cases of childhood $\mathrm{ALL}^{22}$ makes this relationship worthy of conclusive study.

The following three additional unresolved questions have developed from the studies of cigarette smoking and adult AML: (1) What is (are) the leukemogen(s) in cigarette smoke? (2) Is the effect of the leukemogen(s) transduced more commonly through mutations involving chromosome 7 and 8 than other chromosomes, for example chromosome 5, the latter, along with chromosome 7, known to be among the two most prevalent chromosomal abnormality in chemotherapy-induced AML $?^{23}$ and (3) Is a particular phenotype of AML more prevalent in smoking-associated AML than in de novo AML?

Unlike the oral and nasal cavities, the laryngotracheobronchial tree, and perhaps the upper gastrointestinal tract, which receive high concentrations of tobacco smoke, and the kidney and urinary bladder, which receive high concentrations of carcinogenic tobacco smoke metabolites, the sites harboring susceptible lymphohematopoietic cells would be subject to concentrations of smoke-containing mutagens present in blood and body fluids. Thus, the genotoxic dose derived from tobacco smoke would be expected to be relatively low compared to sites directly in contact with cigarette smoke. However, given the strong addictive effect of nicotine in tobacco, the duration of the exposure often would be long.

The smoke of combusted tobacco is estimated to contain over 3800 chemicals of which over half are considered potential toxins or carcinogens. ${ }^{24}$ Studies of the genotoxic effect of mainstream cigarette smoke and cigarette smoke condensate have verified that they induce an increase in micronuclei formation and in chromatid exchange in lymphocytes and myeloid tissues. One focus of the link between smoking and leukemia has been on the content of benzene in tobacco smoke, ${ }^{25-29}$ although numerous other potential toxins in cigarette smoke are also candidates. ${ }^{24,30-32}$ Benzene exposure in an occupational setting, if over a threshold concentrationtime exposure (e.g. 20-40 ppm-years) is a documented cause of AML. The threshold level of benzene that is leukemogenic is not precisely known. ${ }^{33,34}$ Susceptibility may also be influenced by polymorphisms in detoxifying enzymes. ${ }^{35}$ The general population is exposed to benzene principally through active and passive cigarette smoking, the emissions from motor vehicles exhausts and the atmospheric content around gasoline stations. ${ }^{34}$ Personal exposure assessment research has indicated that an average cigarette smoker inhales 6-10 times the benzene inhaled by an average nonsmoker, and that approximately $90 \%$ of a smoker's benzene exposure is from smoking. ${ }^{26,28}$

The benzene metabolites, catechol and hydroxyquinone, are increased about $80 \%$ and trans-muconic acid about $40 \%$ in the urine of smokers as compared to non-smokers. ${ }^{29}$ Benzene metabolism is complex and incompletely understood. ${ }^{33}$ Meta- 
bolites of benzene derived initially from liver enzyme action (e.g. catechol and hydroxyquinone) are surmised to be converted to toxic derivatives in the marrow, based on studies in animals and of isolated lymphohematopoietic cell (including CD34-positive marrow cells); and, in the marrow they are responsible for inducing DNA damage and impairing DNA repair in hematopoietic cells. ${ }^{33}$ Although the concentration of specific genotoxic derivatives of benzene in marrow has been disputed, acute myelogenous leukemogenicity is not in dispute, which is based on the numerous epidemiological studies of industrial populations. ${ }^{33,34}$

The possible role of benzene in cigarette smoke to the induction of AML was questioned in an early report, when the authors considered the occupational exposure to benzene as a requirement to increase rates of AML. These authors concluded that the amount of benzene in cigarette smoke probably would not explain a relative risk, which is twice that of the nonsmoker. ${ }^{2}$ In a more recent report, the investigators estimated that the lifetime exposure of benzene in cigarette smoke contributed $12-58 \%$ of all smoking-related AML deaths. ${ }^{28}$ If so, one would infer that benzene is an important but not sole contributor to smoking-associated AML. The effect of cigarette smoking on death from other cancers and from heart and lung diseases, which are the dominant smoking-induced causes of death, may leave a residual population of smokers, some of whom would die of AML and a proportion of whom may be principally affected by benzene exposure in cigarette smoke.

Several studies have examined the relationship of cytogenetic abnormalities to patients with AML who were cigarette smokers. Table 1 summarizes the cytogenetic findings in cigarette smokers with AML. Most striking is the frequency of reports of abnormalities of chromosome 8 , especially trisomy $8^{36,37}$ and $t(8 ; 21)^{36,38}$ and of chromosome $7 .^{39-41}$ One report found an association of AML with chromosome 5 abnormalities in patients who smoked cigarettes. ${ }^{36}$ Although the data are insufficient to reach firm conclusions, the apparent relative frequency of associations with chromosome 8 is in contradistinction to data on chemotherapy-associated AML. ${ }^{42}$ Studies of the effect of benzene metabolites on cells in culture ${ }^{43-47}$ and of cases of AML linked to industrial exposure to benzene $e^{48-50}$ have found that loss of all or part of chromosomes 5 and 7 and gain or loss in chromosome 8 , or $t(8 ; 21))$ are the prevalent changes. The similarities to the chromosome abnormalities found in smoking-associated $\mathrm{AML}$, however, cannot be considered a basis to make the connection between smokingassociated AML and benzene, since abnormalities in 5 and 7 are

Table 1 Cytogenetic abnormalities in AML/MDS patients who were smokers

Population studied
472 patients with AML in
England. Examined the odds of
being a smoker with AML and
having a specific cytogenetic
abnormality.
168 patients with AML in
Sweden who were smokers
had their cytogenetic
abnormalities compared to 166
patients with AML who were
non-smokers.
330 patients with MDS in
Sweden

79 patients with AML/MDS in Italy

84 patients with $\mathrm{AML}$ with acute myeloblastic leukemia with or without maturation (excluded other phenotypes) in United States

378 patients with AML in United States and Canada

\section{Cytogenetic findings}

$t(8 ; 21)$ only abnormality that correlated with smokers with $A M L$. $O R=4.8$

$(\mathrm{Cl}=1.8-13)$ for 'ever smoked' versus 'never smoked'; $\mathrm{OR}=7.0(\mathrm{Cl}=2.6-19)$ for 'current smoker' versus 'neversmoked'

No significant difference in the categories of cytogenetic changes between the two groups.

Chromosome 7 abnormalities associated with smoking. $\mathrm{OR}=5.0(\mathrm{Cl}=1.5-23)$ (especially $-7 / 7 q-) . O R=2.4(C l=0.61$ 9.3) for association with chromosome 8 but not statistically significant.

Patients with AML who were smokers had an increased frequency of chromosome 8 abnormalities (especially +8 ) compared to non-smokers $\mathrm{OR}=6.3(\mathrm{Cl}=0.9-42)$. If limited to smokers of $\geqslant 10$ cigarettes per day, $\mathrm{OR}=14(\mathrm{Cl}=1.4-142)$.

Patients divided into NN vs AA/AN groups. Cigarette smoking associated weakly with propensity to have abnormal cytogenetics. The greater the number of cigarettes smoked the greater the likelihood.

Frequency of $-7 / 7 q^{-},+13$, and $-Y$ were increased in cigarette smokers with $A M L$ compared to non-smokers with AML. The relationship with $-7 / 7 q^{-},-Y$ and +8 was stronger in patients with the two subtypes: $\mathrm{AML}$ with and without maturation.
Comments

Reference

No statistically significant association with other cytogenetic abnormality.

Moorman et al. ${ }^{38}$

$\mathrm{OR}=2.2(\mathrm{Cl}=0.80-6.2)$ for smokers compared to non-smokers with -7 or $7 q$ but not statistically significant. Acute erythroleukemia and acute monocytic leukemia more prevalent among smokers. Very small numbers, however. Cigarette smoking more closely associated with clonal anemia (refractory anemia) than oligoblastic myelogenous leukemia (RAEB) and AML (RAEB-t).

Bjork et al. ${ }^{40}$

Bjork et al. ${ }^{41}$

Relatively small number of patients. Compare the results against their prior series of patients (No. =129). OR for specific cytogenetics abnormality among smokers with AML vs non-smokers with AML in the two series were similar: $\mathrm{OR}=1.5$ and 1.5 for $5-/ 5 q^{-}, \mathrm{OR}=2.1$ and 1.6 for +8 and $\mathrm{OR}=1.7$ and 2.4 for $t(8 ; 21)$.

Smokers $\geqslant 60$ years had increased risk of $A M L, O R=2.0(C l=1.2-3.3)$. Cigarette smoking was associated with ALL in patients $\geqslant 60$ years of age $\mathrm{OR}=3.4$ $(\mathrm{Cl}=1.0-12)$.
Crane et al. ${ }^{36}$

Sandler et al. ${ }^{39}$

Abbreviations: AA, all metaphases examined with cytogenetic abnormality; ALL, acute lymphocytic leukemia; AML, acute myelogenous leukemia; AN, cytogenetic abnormality but admixed with normal metaphases; Cl, confidence interval; MDS, myelodysplastic syndrome; NN, no cytogenetic abnormality; OR, odds ratio. 
frequent in other cases of chemically (chemotherapy)-induced AML. The similarity between cigarette smoking-associated AML and occupational benzene exposure-induced $\mathrm{AML}$ in the prevalence of chromosome 8 abnormalities, likewise is not a conclusive finding.

A relationship of the phenotype of AML in those patients who are cigarette smokers has been examined looking for subtypes that are over- or underrepresented in smokers. Once again, insufficient study does not permit firm conclusions on whether one or another phenotype is more prevalent among cigarette smokers. Also, studies have been limited by total number of AML cases, which after stratification into subtypes, leaves fewer number of observations. Several studies have found a significant predominance of AML with maturation. ${ }^{51,52}$ A study of 412 cases of AML diagnosed between 1987 and 1994 in Los Angeles County, California, found a modest overall risk of AML among smokers $(\mathrm{OR}=1.2$, confidence interval $(\mathrm{Cl})=0.9-1.6)$. When stratified by $\mathrm{AML}$ subtype, patients with $\mathrm{AML}$ with maturation were more likely to have smoked $(\mathrm{OR}=2.3, \mathrm{Cl}=1.1-4.4)$ and if patients aged more than 60 years with AML with maturation were examined, they were even more likely to have been smokers $(\mathrm{OR}=3.3 \mathrm{Cl}=1.1-10)$. In patients with $\mathrm{AML}$ with maturation, the association with smoking was related to the number of cigarettes smoked per day and duration of cigarette smoking. These investigators estimated that $42 \%$ of patients with AML with maturation had smoking-induced leukemia. ${ }^{51}$

Cancer and Leukemia Group B, a multi-institutional cooperative cancer treatment group in the United States and Canada, investigated the leukemia risk associated with cigarette smoking in 610 adults, aged 18-79 years, with newly diagnosed acute leukemia. ${ }^{52}$ Patients were classified by subtype of acute leukemia. The odds ratio for risk of acute leukemia associated with smoking controlled for age, race and sex was $1.1(0.89$ 1.4). However, in patients $\geqslant 60$ years with $\mathrm{AML}$, the $\mathrm{OR}$ was 2.0 $(\mathrm{Cl}=1.2-3.3)$. Among patients $\geqslant 60$ years, the risk increased with an increase of cigarettes per day smoked. When examined by subtype of $A M L$, risk for $A M L$ with maturation increased at all ages: $\mathrm{OR}=1.7 \quad(\mathrm{Cl}=1.0-2.9)$ for patients $<60$ years and $\mathrm{OR}=3.5(\mathrm{Cl}=1.5-8.0)$ for those $>60$ years of age. This study also found an association between cigarette smoking and ALL in adults $\geqslant 60$ years of age. In these two studies, the OR for smokers $\geqslant 60$ years having AML with maturation compared to non-smokers was 3.3 and 3.5, respectively. Although the first study cited ${ }^{51}$ found chromosome 8 abnormalities to be the most prevalent in cigarette smoking-associated $\mathrm{AML}$, the latter study ${ }^{51}$ did not. In another study, acute erythroleukemia was associated with cigarette smoking but the case numbers were quite low. ${ }^{40}$

Cigarette smoking as an environmental cause of AML merits additional study. The development of further knowledge regarding the leukemogen(s) involved, whether the leukemogen(s) has a propensity to induce a specific phenotype, and the underlying genetic determinants of such an association would be of pathobiological interest. The seeming predisposition to abnormalities of chromosome 8 and to AML with maturation, each associated with the other in de novo $\mathrm{AML}$, is titillating but far from conclusive. Future studies of sufficient statistical power to answer these questions would be useful. These questions represent a challenge and an opportunity to the international cooperative groups studying AML.

\footnotetext{
MA Lichtman ${ }^{1,2}$

${ }^{1}$ Department of Medicine, University of Rochester Medical Center, Elmwood Avenue, Rochester, NY, USA and ${ }^{2}$ Department of Biochemistry and Biophysics, University of
}

\section{Rochester Medical Center, Elmwood Avenue, Rochester, NY, USA \\ E-mail:mal@urmc.rochester.edu}

\section{References}

1 James I of England. A Counterblaste to Tobacco. Barker R, Imprinted at London, 1604 www.luminarium.org/sevenlit/james/ jamesbib.htm. Accessed 14 March 2007.

2 Austin H, Cole P. Cigarette smoking and leukemia. J Chronic Dis 1986; 39: 417-421.

3 Thomas $X$, Chelghoum Y. Cigarette smoking and acute leukemia. Leuk Lymphoma 2004; 45: 1103-1109.

4 Brownson RC, Novotny TE, Perry MC. Cigarette smoking and adult leukemia. A meta-analysis. Arch Intern Med 1993; 153: 469-475.

5 Consequences of Smoking.Executive Summary. United States Surgeon General's Office Report 2004. www.surgeongeneral. gov/library/smokingconsequences/. Accessed 14 March 2007.

6 On the evaluation of carcinogenic risks of chemicals to humans. Tobacco smoke and involuntary smoking. IARC Monographs 2004; 83: 821-837.

7 Siegel M. Smoking and leukemia: evaluation of a causal hypothesis. Am J Epidemiol 1993; 138: 1-9.

8 Severson RK. Cigarette smoking and leukemia. Cancer 1987; 60: 141-144.

9 Wald NJ, Hackshaw AK. Cigarette smoking: an epidemiological overview. Br Med Bull 1996; 52: 3-11.

10 Bjork J, Albin M, Mauritzson N, Stromberg U, Johansson B, Hagmar L. Smoking and myelodysplastic syndromes. Epidemiology 2000; 11: 285-291.

11 Pasqualetti P, Festuccia V, Acitelli P, Collacciani A, Giusti A, Casale R. Tobacco smoking and risk of haematological malignancies in adults: a case-control study. Br J Haematol 1997; 97: 659-662.

12 Chelghoum Y, Danaila C, Belhabri A, Charrin C, Le QH, Michallet $M$ et al. Influence of cigarette smoking on the presentation and course of acute myeloid leukemia. Ann Oncol 2002; 13: $1621-1627$.

13 Ji BT, Shu XO, Linet MS, Zheng W, Wacholder S, Gao YT et al. Paternal cigarette smoking and the risk of childhood cancer among offspring of nonsmoking mothers. J Natl Cancer Inst 1997; 89: 238-244.

14 Cnattingius S, Zack M, Ekbom A, Gunnarskog J, Linet M, Adami HO. Prenatal and neonatal risk factors for childhood myeloid leukemia. Cancer Epidemiol Biomarkers Prev 1995; 4: 441-445.

15 Menegaux F, Steffen C, Bellec S, Baruchel A, Lescoeur B, Leverger $\mathrm{G}$ et al. Maternal coffee and alcohol consumption during pregnancy, parental smoking and risk of childhood acute leukaemia. Cancer Detect Prev 2005; 29: 487-493.

16 Brondum J, Shu XO, Steinbuch M, Severson RK, Potter JD, Robison LL. Parental cigarette smoking and the risk of acute leukemia in children. Cancer 1999; 85: 1380-1388.

17 John EM, Savitz DA, Sandler DP. Prenatal exposure to parents' smoking and childhood cancer. Am J Epidemiol 1991; 133: 123-132.

18 Stjernfeldt M, Berglund K, Lindsten J, Ludvigsson J. Maternal smoking during pregnancy and risk of childhood cancer. Lancet 1986; 1: 1350-1352.

19 Mucci LA, Granath F, Cnattingius S. Maternal smoking and childhood leukemia and lymphoma risk among 1,440,542 Swedish children. Cancer Epidemiol Biomarkers Prev 2004; 13: 1528-1533.

20 Chang JS, Selvin S, Metayer C, Crouse V, Golembesky A, Buffler PA. Parental smoking and the risk of childhood leukemia. Am J Epidemiol 2006; 163: 1091-1100.

21 Tredaniel J, Boffetta P, Little J, Saracci R, Hirsch A. Exposure to passive smoking during pregnancy and childhood, and cancer risk: the epidemiological evidence. Paediatr Perinat Epidemiol 1994; 8: 233-255

22 Greaves M. In utero origins of childhood leukaemia. Early Hum Dev 2005; 81: 123-129.

23 Smith SM, Le Beau MM, Huo D, Karrison T, Sobecks RM, Anastasi J et al. Clinical-cytogenetic associations in 306 patients with 
therapy-related myelodysplasia and myeloid leukemia: the University of Chicago series. Blood 2003; 102: 43-52.

24 On the evaluation of carcinogenic risks of chemicals to humans. Chemistry and analysis of tobacco smoke. IARC Monographs 1985; 38: 83-126.

25 Wallace LA. Major sources of benzene exposure. Environ Health Perspect 1989; 82: 165-169.

26 Wallace L. Environmental exposure to benzene: an update. Environ Health Perspect 1996; 104 (Suppl 6): 1129-1136.

27 Darrell KG, Figgins JA, Brown RD, Phillips GF. Determination of benzene and associated volatile compounds in mainstream cigarette smoke. Analyst 1998; 123: 1095-1101.

28 Korte JE, Hertz-Picciotto I, Schulz MR, Ball LM, Duell EJ. The contribution of benzene to smoking-induced leukemia. Environ Health Perspect 2000; 108: 333-339.

29 Ong CN, Lee BL, Shi CY, Ong HY, Lee HP. Elevated levels of benzene-related compounds in the urine of cigarette smokers. Int J Cancer 1994; 59: 177-180.

30 Hecht SS, Hoffmann D. Tobacco-specific nitrosamines, an important group of carcinogens in tobacco and tobacco smoke. Carcinogenesis 1988; 9: 875-884.

31 Mitacek EJ, Brunnemann KD, Polednak AP, Limsila T, Bhothisuwan K, Hummel CF. Rising leukemia rates in Thailand: the possible role of benzene and related compounds in cigarette smoke. Oncol Rep 2002; 9: 1399-1403.

32 Darrell KG, Figgins JA, Brown RD, Phillips GF. Determination of benzene and associated volatile compounds in mainstream cigarette smoke. Analyst 1998; 123: 1095-1101.

33 Snyder R. Benzene and leukemia. Crit Rev Toxicol 2002; 32: 155-210.

34 Duarte-Davidson R, Courage C, Rushton L, Levy L. Benzene in the environment: an assessment of the potential risks to the health of the population. Occup Environ Med 2001; 58: 2-13.

35 Kim SY, Choi JK, Cho YH, Chung EJ, Paek D, Chung HW. Chromosomal aberrations in workers exposed to low levels of benzene: association with genetic polymorphisms. Pharmacogenetics 2004; 14: 453-463.

36 Crane MM, Strom SS, Halabi S, Berman EL, Fueger JJ, Spitz MR et al. Correlation between selected environmental exposures and karyotype in acute myelocytic leukemia. Cancer Epidemiol Biomarkers Prev 1996; 5: 639-644.

37 Davico L, Sacerdote C, Ciccone G, Pegoraro L, Kerim S, Ponzio G et al. Chromosome 8, occupational exposures, smoking, and acute nonlymphocytic leukemias: a population-based study. Cancer Epidemiol Biomarkers Prev 1998; 7: 1123-1125.

38 Moorman AV, Roman E, Cartwright RA, Morgan GJ. Smoking and the risk of acute myeloid leukaemia in cytogenetic subgroups. $\mathrm{Br} J$ Cancer 2002; 86: 60-62.

39 Sandler DP, Shore DL, Anderson JR, Davey FR, Arthur D, Mayer RJ et al. Cigarette smoking and risk of acute leukemia: associations with morphology and cytogenetic abnormalities in bone marrow. J Natl Cancer Inst 1993; 85: 1994-2003.

40 Bjork J, Albin M, Mauritzson N, Stromberg U, Johansson B, Hagmar L. Smoking and acute myeloid leukemia: associations with morphology and karyotypic patterns and evaluation of doseresponse relations. Leuk Res 2001; 25: 865-872.

41 Bjork J, Albin M, Mauritzson N, Stromberg U, Johansson B, Hagmar L. Smoking and myelodysplastic syndromes. Epidemiology 2000; 11: 285-291.

42 Godley LA, LeBeau MM. Cytogenetics and Gene rearrangement. In: Lichtman MA, Beutler E, Kipps TJ, Seligsohn U, Kaushansky K, Prchal JT (eds) Williams Hematology, 7th edn, McGraw-Hill Company: New York, 2006, pp 137-150.

43 Zhang L, Yang W, Hubbard AE, Smith MT. Nonrandom aneuploidy of chromosomes $1,5,6,7,8,9,11,12$, and 21 induced by the benzene metabolites hydroquinone and benzenetriol. Environ Mol Mutagen 2005; 45: 388-396.

44 Smith MT, Zhang L, Jeng M, Wang Y, Guo W, Duramad P et al. Hydroquinone, a benzene metabolite, increases the level of aneusomy of chromosomes 7 and 8 in human CD34-positive blood progenitor cells. Carcinogenesis 2000; 21: 1485-1490.

45 Stillman WS, Varella-Garcia M, Irons RD. The benzene metabolites hydroquinone and catechol act in synergy to induce dose-dependent hypoploidy and $-5 \mathrm{q} 31$ in a human cell line. Leuk Lymphoma 1999; 35: 269-281.

46 Stillman WS, Varella-Garcia M, Irons RD. The benzene metabolite, hydroquinone, selectively induces $5 q 31-$ and -7 in human CD34+CD19- bone marrow cells. Exp Hematol 2000; 28: 169-176.

47 Zhang L, Rothman N, Wang Y, Hayes RB, Li G, Dosemeci M et al. Increased aneusomy and long arm deletion of chromosomes 5 and 7 in the lymphocytes of Chinese workers exposed to benzene. Carcinogenesis 1998; 19: 1955-1961.

48 Smith MT, Zhang L, Wang Y, Hayes RB, Li G, Wiemels J et al. Increased translocations and aneusomy in chromosomes 8 and 21 among workers exposed to benzene. Cancer Res 1998; 58: 2176-2181.

49 Zhang L, Eastmond DA, Smith MT. The nature of chromosomal aberrations detected in humans exposed to benzene. Crit Rev Toxicol 2002; 32: 1-42.

50 Kasuba V, Rozgaj R, Sentija K. Cytogenetic changes in subjects occupationally exposed to benzene. Chemosphere 2000; 40: 307-310.

51 Pogoda JM, Preston-Martin S, Nichols PW, Ross RK. Smoking and risk of acute myeloid leukemia: results from a Los Angeles County case-control study. Am J Epidemiol 2002; 155: 546-553.

52 Sandler DP, Shore DL, Anderson JR, Davey FR, Arthur D, Mayer RJ et al. Cigarette smoking and risk of acute leukemia: associations with morphology and cytogenetic abnormalities in bone marrow. J Natl Cancer Inst 1993; 85: 1994-2003. 